\title{
Persepsi Terhadap Dukungan Orangtua dan Kesulitan Pengambilan Keputusan Karir Pada Remaja
}

\author{
Esty Fitrah Islamadina, Alma Yulianti \\ Fakultas Psikologi UIN Sultan Syarif Kasim Riau \\ email: estyfislamadina@gmail.com
}

\begin{abstract}
Abstrak
Penelitian ini bertujuan untuk meneliti secara empirik hubungan antara persepsi terhadap dukungan orangtua dengan kesulitan pengambilan keputusan karir pada remaja. Penelitian ini melibatkan 261 sampel yang ditentukan melalui teknik mixed sampling yaitu perpaduan random dan non-random, random sederhana untuk kategori random dan purposive sampling untuk kategori non-random. Data penelitian dikumpulkan melalui skala Perception of Parents Scale (POPS-Robbins, 1994) dan skala Career Decision-making Difficulties Questionaire (CDDQ-Gati, 1996). Hipotesis penelitian ini adalah ada hubungan negatif dan signifikan antara persepsi terhadap dukungan orangtua dan kesulitan pengambilan keputusan karir pada remaja. Hasil analisis korelasi product moment menunjukkan adanya hubungan negatif yang sangat signifikan antara persepsi terhadap dukungan orangtua dan pengambilan keputusan karir pada remaja dengan korelasi sebesar $r=-0,220$ dan signifikansi $p=0,000$. Artinya, semakin positif persepsi remaja terhadap dukungan orangtua maka semakin rendah kesulitan yang dirasakan oleh remaja dalam mengambil keputusan karir.
\end{abstract}

Kata kunci: persepsi terhadap dukungan orangtua, kesulitan pengambilan keputusan karir, remaja

\section{Perceptions of Parental Support and Career Decision-Making Difficulties In Adolescents}

\begin{abstract}
This study aims to examine empirically the relationship between perceptions of parental support with career decision-making difficulties in adolescents. The study included 261 samples were determined through mixed sampling technique which is a combination of random and non-random, simple random for random and purposive sampling category to the category of non-random. The research data were collected through the scale Perception of Parents Scale (POPS-Robbins, 1994) and the scale of the Career Decision-making Difficulties Questionnaire (CDDQ-Gati, 1996). The hypothesis of this study is a negative correlation and significant correlation between perceptions of parental support and career decision-making difficulties in adolescents. The results of product moment correlation analysis showed a significant negative relationship between perceptions of parental support and career decision-making in adolescents with a correlation of $r=-0.220$ and significance of $p=0.000$. The meaning, the positive perception of adolescents to parental support, the lower difficulties experienced by adolescents in career decision-making.
\end{abstract}

Keywords: perception of parental support, career decision-making difficulties, adolescents

\section{Pendahuluan}

Manusia merupakan organisme sosial yang dalam berinteraksi dengan lingkungannya harus memilih dan membuat keputusan untuk menyelesaikan masalah. Pembuatan atau pengambilan keputusan itu sendiri merupakan suatu proses memilih atau menentukan berbagai kemungkinan di antara situasi-situasi yang tidak pasti. Pembuatan keputusan terjadi di dalam situasi-situasi dimana seseorang harus membuat prediksi kedepan, memilih salah satu diantara dua pilihan atau lebih, atau membuat estimasi mengenai frek- uensi kejadian berdasarkan bukti-bukti yang terbatas (Suharnan, 2005). Oleh karena itu, tiap individu harus menyadari bahwa ketika telah memilih sebuah pilihan, maka individu tersebut harus menerima dan bertanggung jawab atas semua konsekuensi dan risiko yang ada pada pilihan tersebut.

Setiap individu menjalani fase-fase perkembangan dimana setiap fase perkembangan memiliki kemampuan pengambilan keputusan yang berbeda-beda. Gieed (1999) menyimpulkan hasil penelitiannya bahwa orang dewasa akan membuat keputusan yang rasional dalam proses pengambilan 
keputusan meskipun dalam keadaan emosional. Sebab orang dewasa memiliki kemampuan mengendalikan emosi dan impuls yang lebih besar dari pada remaja. Sementara itu, otak remaja belum siap untuk memikirkan segala sesuatu dengan cara yang sama seperti orang dewasa. Oleh sebab itu, remaja cenderung membuat keputusan yang irasional.

Masa remaja merupakan masa dimana meningkatnya pengambilan keputusan. Remaja yang lebih tua agaknya lebih kompeten dan lebih baik dalam mengambil keputusan dibandingkan dengan remaja yang lebih muda (Lewis, 1981). Sebagian besar orang dapat mengambil keputusan secara lebih baik, apabila mereka dalam kondisi tenang dibandingkan apabila mereka sedang berada dalam kondisi emosional. Secara khusus, hal ini berlaku untuk remaja. Remaja dapat mengambil keputusan yang bijaksana ketika suasana hatinya tenang. Namun mungkin saja dapat mengambil keputusan yang tidak bijaksana ketika sedang berada dalam kondisi emosional sebab pada dasarnya remaja memiliki kesulitan dalam mengontrol perilaku mereka (Santrock, 2007).

Menurut Super (Osipow, 1983) tugas perkembangan karir remaja berada pada tahap eksplorasi, pada tahap ini remaja mulai memikirkan alternatif pekerjaan, pencarian peran dan jati diri di sekolah. Pendapat tersebut menggambarkan bahwa remaja pada tahap perkembangan karir, mulai mengidentifikasi jenis pekerjaan yang sesuai dengan bakat, minat, serta potensi yang dimilikinya. Namun, tidak semua remaja dapat dengan mudah mengambil keputusan karir sebab remaja harus berusaha mengatasi ketidakjelasan mengenai kapabilitasnya, kestabilan minat, prospek alternatif pilihan untuk saat ini dan masa yang akan datang, aksesibilitas karir dan identitas yang ingin dikembangkan dalam diri mereka sendiri (Bandura dalam Sawitri, 2009). Hal ini yang mengakibatkan banyak diantara remaja mengalami keraguan dalam memilih suatu jalur karir (Creed, Patton, \& Prideaux, 2006). Hal ini sesuai dengan hasil wawancara dari beberapa siswasiswi Sekolah Lanjutan Tingkat Atas (SLTA), dimana dapat disimpulkan bahwa mereka memiliki minat pada satu atau beberapa bidang karir, namun masih merasa bingung dan ragu terhadap pilihan tersebut sebab bidang karir yang mereka minati kerap berubahubah, banyaknya pilihan karir yang tersedia, dan tidak percaya diri pada bakat dan kemampuan yang dimiliki.

Gati dan Saka (2001) melakukan studi terhadap 1843 remaja Israel, tentang jenis keputusan yang dihadapi remaja kelas IX, $\mathrm{X}$ dan XI. Pengambilan keputusan tersebut berkaitan dengan memilih sekolah menengah lanjutan (bagi siswa kelas IX), memilih juru- san (siswa kelas X), dan menentukan pilihan pekerjaan dalam dunia militer (siswa kelas XI). Hasil penelitiannya antara lain menyimpulkan bahwa masalah yang banyak dihadapi siswa adalah masalah kependidikan (43\%, seputar pendidikan dan karir). Temuan diatas diperkuat dengan hasil penelitian Hayadin (2007) mayoritas siswa-siswi Sekolah Menengah Atas (SMA), Madrasah Aliyah (MA), dan Sekolah Menengah Kejuruan (SMK), $64,25 \%$ belum memiliki keputusan yang jelas tentang profesi yang akan digelutinya. Fakta lain ditemukan dari hasil analisis instrumen perkembangan dan wawancara yang dilakukan Rachmaniar (2012) bahwa 80\% peserta didik mengalami hambatan dalam pembuatan keputusan karir yang akan dijalaninya di masa depan. Hasil penelitian Muhajirin (2014) juga membuktikan bahwa profil kesulitan membuat keputusan karir yang dialami peserta didik kelas XI SMAN 3 Bandung berada pada kategori tinggi. Fakta empiris tersebut menujukkan bahwa kesulitan dalam mengambil keputusan karir dan keraguan karir remaja merupakan gejala faktual yang dialami remaja.

Keraguan yang dialami tersebut termanifestasi sebagai kesulitan-kesulitan yang dihadapi remaja ketika memutuskan karir (Gati, Krausz \& Osipow, 1996). Kesulitan-kesulitan ini dapat menjadikan remaja menyerahkan tanggung jawab pengambilan keputusan pada orang lain, atau menunda dan menghindar dari tugas mengambil keputusan, yang dapat mengakibatkan pengambilan keputusannya tidak optimal. Tekanan yang dirasakan dapat mempengaruhi beragam aspek kehidupan sehari-hari, cara remaja mengambil keputusan akan mempengaruhi caranya mengambil keputusan karir di masa depan (Gati \& Saka, 2001).

Menurut Robbins (1994) terdapat tiga dimensi persepsi terhadap dukungan orangtua yaitu dukungan otonomi, keterlibatan, dan kehangatan. Menurut Keller (2004) ketika remaja merasa didukung dan dicintai oleh orangtua, remaja memiliki lebih banyak keterampilan dalam berpikir tentang karir dan dunia kerja daripada ketika remaja merasa tidak didukung dan dicintai oleh orangtua. Sehingga remaja yang merasa didukung dan dicintai akan menimbulkan persepsi terhadap dukungan orangtua.

Dukungan dan rasa cinta yang diberikan oleh orangtua dapat menyebabkan kurangnya informasi yang dimiliki remaja menjadi rendah. Hasil penelitian yang dilakukan oleh Keller (2004) menunjukkan bahwa ketika remaja didukung dan dicintai oleh orangtua, remaja memiliki percaya diri yang tinggi dalam kemampuan untuk menemukan informasi karir dan memilih karir yang mereka minati. Jadi persepsi terhadap dukungan orangtua yang dimiliki remaja dapat memberi- 
kan pengaruh pada kesulitan pengambilan keputusan karir.

Persepsi merupakan suatu proses yang didahului oleh proses penginderaan, yaitu merupakan proses diterimanya stimulus oleh individu melalui alat indera. Stimulus diterima oleh alat indera, dan melalui proses penginderaan tersebut stimulus itu menjadi suatu yang berarti setelah diorganisasikan dan diinterpretasikan (Davidoff dalam Walgito, 2010). Dengan adanya persepsi mengenai dukungan dari orangtua dapat menimbulkan rasa aman dalam melakukan partisipasi aktif, eksplorasi, dan eksperimentasi dalam kehidupan remaja yang pada akhirnya akan menghasilkan peningkatan rasa percaya diri, keterampilan-keterampilan dan strategi-strategi coping sehingga remaja akan merasa aman dan lebih percaya diri untuk menghadapi situasi-situasi baru dan tantangan. (Cutrona, Cole, dkk, 1994).

Berdasarkan pemaparan fenomena di atas, peneliti tertarik untuk melihat apakah ada hubungan antara persepsi terhadap dukungan orangtua dan kesulitan pengambilan keputusan karir pada remaja.

Menurut Kamus Besar Bahasa Indonesia (KBBI) kesulitan diartikan sebagai keadaan yang sulit atau sesuatu yang sulit. Menurut Narayan dan Corcoran-Perry (Sanz de Acedo Lizarraga.dkk, 2007) menganggap pengambilan keputusan sebagai interaksi antara masalah yang perlu dipecahkan dan individu yang ingin menyelesaikannya dalam lingkungan tertentu. Sementara itu menurut Anoraga (2001) karir dalam arti sempit adalah profesi serta kedudukan dalam kehidupan sebagai upaya mencari nafkah, sedangkan karir dalam arti luas adalah langkah maju sepanjang hidup yang berkaitan dengan pekerjaan dan jabatan yang dimiliki seseorang. Gati, Krausz, dan Osipow (1996) mendefinisikan bahwa setiap penyimpangan dari proses pengambilan keputusan karir yang ideal sebagai kesulitan yang dapat menyebabkan kebingungan atau pengambilan keputusan karir yang kurang optimal

Kesulitan pengambilan keputusan karir adalah suatu keadaan dimana individu berada pada situasi yang sulit untuk menghasilkan suatu tindakan melalui proses evaluasi dari beberapa jumlah alternatif aktivitas pekerjaan yang telah dibuat yang melibatkan operasi kognitif, perilaku, kemampuan, dan sikap untuk dapat menentukan salah satu alternatif dari sejumlah alternatif yang didasari pengetahuan tentang diri dan informasi yang befungsi untuk memecahkan masalah.

Menurut Gati, Krausz, dan Osipow (1996) kesulitan dalam pengambilan keputusan karir memiliki tiga aspek, yaitu:

1. Kurangnya kesiapan

Aspek ini berisi keengganan untuk mem- buat keputusan karir, ketidaktegasan dalam membuat keputusan, memiliki keyakinan yang disfungsional dan kurangnya pengetahuan tentang proses pembuatan keputusan karir

2.Kurangnya informasi

Aspek ini mencakup kurangnya informasi tentang diri, pekerjaan, dan cara memperoleh informasi tambahan

3.Informasi yang tidak konsisten.

Aspek ini mengacu pada adanya informasi yang tidak dapat diandalkan dan adanya konflik baik internal maupun eksternal.

Persepsi menurut Atkinson dan Hilgard (1999) adalah proses dimana individu menafsirkan dan mengorganisasikan pola stimulus dalam lingkungan. Sebagai cara pandang, persepsi timbul karena adanya respon terhadap stimulus. Stimulus yang diterima seseorang sangat kompleks, stimulus masuk ke dalam otak, kemudian diartikan, ditafsirkan serta diberi makna melalui proses yang rumit baru kemudian dihasilkan persepsi. Menurut Gottlieb (Smet, 1994) mengungkapkan bahwa dukungan sosial terdiri dari informasi atau nasehat verbal atau non verbal, bantuan nyata, atau tindakan yang diberikan oleh keakraban sosial atau didapat karena kehadiran mereka dan mempunyai manfaat emosional atau efek perilaku bagi pihak penerima.

Persepsi terhadap dukugan orangtua merupakan respon yang dihasilkan dari stimulus berupa perasaan keterikatan yang dianggap penuh cinta atau peduli, bantuan nyata, atau tindakan yang diberikan seperti kehadiran kemudian diterima melalui penginderaan dan diproses di dalam otak sehingga menghasilkan sesuatu yang berarti setelah diorganisasi dan diinterpretasi.

Menurut Robbins (1994) persepsi terhadap dukungan orangtua memiliki tiga dimensi, yaitu:

a. Dukungan Otonomi, yaitu memberikan dorongan kepada anak dengan tujuan kemandirian dapat terbentuk pada anak

b. Keterlibatan, yaitu orangtua yang terlibat dalam setiap proses perkembangan anak sehingga tercipta hubungan emosianal seperti dukungan, keterlibatan, dan hubungan pribadi. Namun, orangtua harus mampu menunjukkan toleransi terhadap kemandirian, keunikan pribadi, dan kebebasan berekspresi anak dalam menghadapi masalah.

c. Kehangatan, yaitu orangtua yang hangat dan responsif ketika berinteraksi dengan anak-anak mereka dimana orangtua secara gamblang menyampaikan kecintaannya kepada anak dan menanggapi kebutuhan khusus anak-anak mereka. 
Piaget (Hurlock, 1989) mengatakan secara psikologis, masa remaja adalah usia di mana individu berintegrasi dengan masyarakat dewasa, usia di mana anak tidak lagi merasa di bawah tingkatan orang-orang yang lebih tua melainkan berada dalam tingkatan yang sama, sekurang-kurangnya dalam masalah hak. Integrasi dalam masyarakat (dewasa) mempunyai banyak aspek efektif, kurang lebih berhubungan dengan masa puber. Termasuk juga perubahan intelektual yang khas dari cara berpikir remaja ini memungkinkannya untuk mencapai integrasi dalam hubungan sosial orang dewasa, yang kenyataannya merupakan ciri khas yang umum dari periode perkembangan ini.

\section{Hipotesis}

Hipotesis penelitian ini adalah "ada hubungan negatif antara persepsi terhadap dukungan orangtua dengan kesulitan pengambilan keputusan karir pada remaja".

\section{Metode}

Subjek

Sampel adalah sebagian atau wakil dari populasi yang akan diteliti (Arikunto, 2010). Teknik sampling yang digunakan adalah mixed sampling. Mixed sampling telah diklasifikasikan ke dalam kategori campuran sampling, karena memiliki karakteristik dari kedua sampling random dan non random (Kumar, 1999). Untuk kategori random, peneliti menggunakan random sederhana dan untuk kategori non random peneliti menggunakan purposive sampling. Jumlah sample dalam penelitian ini adalah sebanyak 261 orang.

\section{Pengukuran}

Instrumen yang digunakan dalam penelitian ini adalah skala Perceptions of Parents Scale (POPS) yang dikembangkan oleh Robbins (1994) dan skala kesulitan pengambilan keputusan karir pada remaja, peneliti menggunakan alat ukur yang didesain oleh Gati, Krausz \& Osipow (1996). Teknik analisis data penelitian diukur dengan meggunakan rumus korelasi Product Moment Pearson.

Sebelum digunakan dalam penelitian, alat ukur diuji coba terlebih dahulu. Dalam penelitian ini alat ukur diuijicobakan kepada 114 responden. Pada skala persepsi terhadap dukungan orangtua, dari 42 aitem setelah diuji cobakan gugur sebanyak 5 aitem. Sedangkan pada skala kesulitan pengambilan keputusan karir, dari 34 aitem setelah diuji cobakan gugur sebanyak 7 aitem.

Koefisien reliabilitas pada skala persepsi terhadap dukungan orangtua sebesar 0,920, dan pada skala kesulitan pengambilan keputusan karir sebesar 0,961.

\section{Hasil}

Berdasarkan hasil analisis Product Moment dari Pearson diperoleh koefisien korelasi $(r)$ sebesar $-0,220$ dengan taraf signifikansi $0,000 \quad(p<0,01)$, artinya hipotesis diterima. Berdasarkan hasil analisis perbedaan berdasarkan jenis kelamin diketahui bahwa tidak ada perbedaan antara laki-laki dan perempuan.

\section{Tabel 1. Uji Hubungan dan Kontribusi Aspek Persepsi Terhadap Dukungan Orangtua Terhadap Kesulitan Pengambilan Keputuan Karir}

\begin{tabular}{lll}
\hline Aspek & Rsq & Persentase (\%) \\
\hline Keterlibatan Ibu & 0,036 & 3,6 \\
Dukungan Otonomi Ibu & $-0,003$ & $-0,3$ \\
Kehangatan Ibu & 0,020 & 2 \\
Keterlibatan Ayah & $-0,003$ & $-0,3$ \\
Dukungan Otonomi Ayah & $-0,001$ & $-0,1$ \\
Kehangatan Ayah & $-0,000$ & 0 \\
\hline Total & & $\mathbf{4 , 9 \%}$ \\
\hline
\end{tabular}

Berdasarkan tabel 1 menunjukkan bahwa aspek yang paling banyak memberikan kontribusi terhadap kesulitan pengambilan keputusan karir adalah keterlibatan ibu, yaitu sebesar $3,6 \%$, dan aspek yang paling kecil kontribusinya adalah keterlibatan ayah dan dukungan otonomi ibu.

\section{Pembahasan}

Ditemukan bahwa persepsi terhadap dukungan orangtua berkorelasi negatif dengan kesulitan pengambilan keputusan karir pada remaja. Hal ini membuktikan bahwa semakin positif persepsi remaja terhadap dukungan orangtua, maka semakin rendah 
kesulitan pengambilan keputusan karir pada remaja. begitu pula sebaliknya semakin negatif persepsi remaja terhadap dukungan orangtua, maka semakin tinggi kesulitan pengambilan keputusan karir pada remaja.

Setelah dimasukkan dalam kategori, secara keseluruhan subjek penelitian berada pada kategori tinggi pada variabel persepsi terhadap dukungan orangtua, ini menunjukkan bahwa sebagian besar persepsi subjek penelitian terhadap dukungan orangtua dapat mengurangi kesulitan dalam pengambilan keputusan karir. Disisi lain, subjek penelitian berada pada kategori sedang pada variabel kesulitan dalam pengambilan keputusan karir, ini menunjukkan bahwa remaja tidak terlalu mengalami kesulitan, tetapi juga tiduk cukup mudah untuk mengambil keputusan karir. Artinya persepsi yang positif akan mempengaruhi rendahnya kesulitan yang dirasakan remaja dalam pengambilan keputusan karir. Sehingga persepsi yang positif terhadap dukungan orangtua dalam penelitian ini akan mengurangi kesulitan yang dirasakan remaja dalam pengambilan keputusan karir.

Berdasarkan analisis uji perbedaan diketahui bahwa tidak terdapat perbedaan antara laki-laki dan perempuan baik dilihat dari persepsi terhadap dukungan orangtua ataupun kesulitan pengambilan keputusan karir.

Hasil analisis korelasi pada setiap aspek persepsi terhadap dukungan orangtua dan kesulitan pengambilan keputusan karir menunjukkan perbedaan persentase dari setiap aspek persepsi terhadap dukungan orangtua tersebut. Aspek keterlibatan ibu merupakan dukungan orangtua yang paling banyak dirasakan oleh remaja jika dilihat dari nilai $R$ squared dengan nilai sebesar 3,8\%. Artinya, aspek keterlibatan ibu memberikan kontribusi terbanyak dalam kesulitan pengambilan keputusan karir pada remaja. Hasil penelitian Grolnick, Ryan, dan Deci (1991) mengungkapkan hal yang tidak jauh berbeda dimana aspek keterlibatan ibu lebih mempengaruhi pengembangan motivasi anak dari pada aspek lain. Persepsi remaja terhadap dukungan orangtua dari aspek keterlibatan ibu seperti menyediakan waktu untuk berbicara dan menghabiskan banyak waktu bersama remaja akan mempengaruhi remaja dalam mengambil keputusan karir terlihat dari remaja yang cukup mampu untuk membuat keputusan dan tidak takut gagal. Sehingga persepsi yang positif terhadap dukungan orangtua yang berasal dari aspek keterlibatan ayah dapat mempengaruhi kesulitan pengambilan keputusan karir pada remaja.

Pada penelitian ini memberikan sumbangsih efektif dari persepsi terhadap dukungan orangtua terhadap kesulitan pengambilan keputusan karir pada remaja yaitu sebesar
$4,9 \%$, artinya semakin positif persepsi remaja terhadap dukungan orangtua menurunkan kesulitan pengambilan keputusan karir yang dimiliki sebesar 4,9\% dan $95,1 \%$ dipengaruhi oleh faktor-faktor selain persepsi terhadap dukungan orangtua, seperti taraf inteligensi, minat, informasi (pengetahuan), status sosial ekonomi keluarga dan pergaulan dengan teman sebaya. Hasil penelitian Naz, dkk (2014) menunjukkan bahwa rekan dan teman-teman mendominasi dalam pilihan akademik dan proses pengambilan keputusan karir pada remaja. Hal inilah yang akan memberikan pengaruh dalam meningkatkan kemampuan pengambilan keputusan karir.

\section{Kesimpulan}

Berdasarkan hasil penelitian dapat ditarik kesimpulan bahwa terdapat hubungan yang negatif antara persepsi terhadap dukungan orangtua dan kesulitan pengambilan keputusan karir pada remaja. Semakin positif persepsi remaja terhadap dukungan orangtua maka semakin rendah kesulitan yang dirasakan remaja dalam pengambilan keputusan karir, semakin negatif persepsi remaja terhadap dukungan orangtua maka semakin tinggi kesulitan yang dirasakan remaja dalan pengambilan keputusan karir.

\section{Daftar Pustaka}

Anoraga, Panji. (2001). Psikologi Kerja. Jakarta: Rineka Cipta

Atkinson, R.L., Atkinson, R.C., Hilgard, E.R. (1999). Pengantar Psikologi: Jilid 1. Jakarta: Erlangga.

Creed, P., Patton, W., Prideaux, L.A. (2006). Antecedents and Concequences of Career Decisional States in Adolescence. Journal Vocational Behavior 2006, Vol. 67, No. 3, 397412.

Cutrona, C.E., Cole, V., Colangelo, N., Assouline, S.G., Russel, D.W. (1994). Perceived Parental Social Support and Academic Achievement: An Attachment Theory Perspective. Journal of Personality and Social Psychology 1994, Vol. 66, No. 2, 369378.

Gati, I., Krausz, M., \& Osipow, S. H. (1996). A taxonomy of difficulties in career decision making. Journal Of Counseling Psychology, 43(4), 510526. doi:10.1037/0022-0167.43.4.510.

Gati, I., \& Saka, N. (2001). High school students' career-related decisionmaking difficulties. Journal of Counseling and Development, 79(3), 331-340.

Gieed, J.N., Blumenthal, J., Jeffries, N.O., 
Castellanos, F.X., Liu,H., Zi jdenbos, A., Paus, T., Evns, A.C., Rapoport, J.L. (1999). Brain Development During Childhood and Adolescence: A Longitudinal MRI Study. Journal Nature Neuroscience, Vol. 2, No. 10 861-869.

Grolnick, Wendy S., Ryan, Richard M., \& Deci, Edward L. (1991). Inner Resources for School Achievement: Motivational Mediators of children's perceptions of Their Parents. Journal of Educational Psychology, Vol. 83, No. 4, 508-517.

Hayadin (2007). Pengambilan Keputusan untuk Profesi pada Siswa Jenjang Pendidikan Menengah (Survei pada SMA, MA, dan SMK di DKI Jakarta). [Online]. Tersedia: http//www.masadepanku.net (24 April 2015)

Hurlock, E. B. (1989). Psikologi Perkembangan Suatu Pendekatan Sepanjang Rentang Kehidupan. Jakarta: Erlangga.

Keller, B. K. (2004). Parental behaviours that influence adolescents' career development. University of Washington, U.S.A

Kumar, Ranjit. (1999). Research Methodology: A Step by Step Guides For Beginners. Sage Publications: London, Thousand Oaks, New Delhi.

Lewis, C. C. (1981). How adolescents approach decisions: Changes over grades seven to twelve and policy implications. Child Development, 52, 538-544.

Monks, F.J \& Knoers, A.M.P. (2006). Psikologi Perkembangan Pengantar Dalam Berbagai Bagiannya. Yogyakarta: Gadjah Mada University Press.

Muhajirin, Muhammad. (2014). Efektivitas Konseling Karir Trait and Factor untuk Mereduksi Kesulitan Membuat Keputusan Karir Peserta Didik. Skripsi. Universitas Pendidikan Indonesia

Naz, Arab., Saeed, Gohar., Khan, Waseem., Khan, Nasim., Sheikh, 'Irum., and Khan, Nasar. (2014). Peer and
Friends and Career Decision Making: Journal of Scientific Research 22 (8): 1193-1197.

Osipow, Samuel. (1983). Theories of Career Development. USA: Prentice-Hall.

Rachmaniar, Ananda. (2012). Program Bimbingan Karir untuk Meningkatkan Kemampuan Pembuatan Keputusan Karir: Penelitian Pra Eksperimen terhadap Peserta Didik Kelas XI SMA Negeri 19 Bandung Tahun Ajaran 2011/2012. Skripsi. Universitas Pendidikan Indonesia.

Robbins, R. J. (1994). An Assessment of Perceptions of Parental Autonomy Support and Control: Child and Parent Correlates. Unpublished Doctoral Dissertation, Department of Psychology, University of Rochester, 1994.

Robbins, S.P. (2002). Prnsip-prinsip Perilaku Organisasi (Edisi kelima). Jakarta: Erlangga.

Santrock, John. W. (2007). Remaja (Edisi 11 Jilid I). Jakarta: Erlangga.

Santrock, John. W. (2007). Remaja (Edisi 11 Jilid II). Jakarta: Erlangga.

Sanz de Acedo Lizarraga, M.L., Sanz de Acedo Baquedano, M.T., CaedelleElawar, Maria. (2007). Factors that Affect Decision Making: Gender and Age Differences. International Journal of Psychology and Psychological Therapy 2007, 7, 3, 381-391.

Sawitri, Dian. R. (2009). Pengaruh Status Identitas Dan Efikasi Diri Keputusan Karir Terhadap Keraguan Pengambilan Keptusan Karir Pada Mahasiswa Tahun Pertama di Universitas Diponegoro. Jurnal Psikologi Undip, Vol. 5, No. 2, 2009.

Smet, Bart (1994). Psikologi Kesehatan. Jakarta: PT Gramedia Widiasarana Indonesia

Survey Data Collection Wave 1: Baseline result May 2012. Pacific Adolescent Career Pathways Report.

Walgito, Bimo. (2010). Pengantar Psikologi Umum. Yogyakarta: C.V Andi Offset. 